\title{
Chivalry in Islamic Period of Azerbaijan
}

\author{
Parisa Ghorbannejad (Corresponding author) \\ Faculty of Science, Islamic Azad University \\ Urmia Branch, West Azarbayjan, Iran
}

Tel: 98-91-4347-3828Ｅmail: P.Gorbannejad@iaurmia.ac.ir; gorbannejad@gmail.com

Received: July 14, 2014 Accepted: August 13, 2014 Published: August 31, 2014

doi:10.5296/ijch.v2i1.5948 URL: http://dx.doi.org/10.5296/ijch.v2i1.5948

\begin{abstract}
Chivalry in Azerbaijan has been mentioned in Sufism related references since fifth Hegira century. Although chivalry in Azerbaijan had interactions with Zarathustra religion and Manichaeism before Islam, but after the entrance of Islam to this region, Sufism and chivalry became close to each other. Sufi knights were moderate in both ideas and behaviors and contributed in social affairs and helped poor people and often appeared by titles like Akhy or $B a b a$. They wore a uniform color to find their counterparts easily and never assumed their manner different from Sharia. After Mogul invasion of Azerbaijan, social chaos increased and chivalry Sufism spread more. Despotism and injustice of Mogul rulers and disability of local governors to encounter them made life harder for people and left them with their difficulties. Thus, the social base for chivalry was prepared in second half of $7^{\text {th }}$ Hegira century and chivalry shaped the main part of Sufism in Azerbaijan through which Sohravidieh and Kebravieh were promoted as evolving movements of it. This article investigates the trend of chivalry in Azerbaijan since $5^{\text {th }}$ century to early Ilkhani era and introduces influential chivalry figures and their manners by an analytic descriptive research method.
\end{abstract}

Keywords: Chivalry, Azerbaijan, Akhys, Sufism

\section{Introduction}

Chivalry, old tradition with its special moral fundamentals, is exclusive for men and is rooted in ancient Iranian religions and traditions. There are evidences of chivalry among lootis, khaksar dervishes and attendants in traditional gymnasiums (Zoorkhaneh). Followers of this tradition are called "fata". They have important and considerable influence on Iran's social evolutions and political history since the first Islamic centuries. They have their own traditions and ethics and new-comers received a written document to learn more about chivalry. This document is called chivalry treatise (fotowat-nameh). After entrance of Islam 
to Iran, chivalry had interaction with Sufism and as an ideology and set of ethics and traditions contained reactions to social affairs. Chivalry accepted and attracted many different reflections and inspirations from spiritual culture of different layers of Islamic society during ups and downs of Islam history. Chivalrous men (fatas) did good works and were faithful to moral principles but some of them committed vice and immorality. Generosity, hospitality and self-sacrifice were specifications reminded by people for Zoorkhaneh attendees and lootis, but some of them were famous for bullying and ransom. The interaction between chivalry and Sufism included a larger aspect and added self-sacrifice to it and totally in social point of view, chivalry expressed humanity principles and values, morality, right and justice wanted to make correction in society in the shadows of intellectual development and moral transformation. Chivalrous men attempted to improve welfare of ordinary people and help oppressed and poor people against oppressors.

No research has been conducted on this topic on Azerbaijan (Note 1) and studies show that history of chivalry in this region after Islam did not begin before $5^{\text {th }}$ Hegira century and political and social crisis had contributions in its formation. The objective of conducting this research is to find answer for unknowns on Iran social history and chivalry circle related to Sufism in Azerbaijan region. How the tradition of chivalry in Azerbaijan was and what made chivalrous famous there? Which Sufism tariqa and what moral principles were followed by them? What was their relation with Khanghah organization? These are the subjects studied by the author in a descriptive, analytical method from its beginning until Ilkhani period according to the evidences.

\section{History of Chivalry and Its Position}

Since the beginning of Sufism a group of Sufis followed a manner (tariqa) called chivalry. Following great names of Islam and mysticism such as Ali-ebne-Abitaleb, fatas or chivalric men took social reformer roles to serve poor layer of the society. Most of them had Shia tendency (Golpinarly, 2000; Al-shoeybi, 1964). and serving oppressed people was considered as the most important step in their mystic evolution. Taking a glance to chivalry treatise, the oldest of which belongs to Abdu-al-Rahman Solomi (d $412 \mathrm{AH}$ ), one can understand that moral virtues such as apology, faith, truth, purity, beneficiation, generosity, patience, kindness, zeal and chastity were important for chivalrous. (Note 2) To clarify the importance of chivalry, it must be mentioned that at the beginning of writing books about theoretical principles and fundamentals of Sufism, primary Islamic mystics such as Hassan Basri (d $110 \mathrm{AH}$ ), Ahmad-ebne-Khozravieh (d 240 AH) and Hamdoon Ghasar (d 271 AH) were quoted (Hojveiri, 1957) and some chapters of these books are allocated to chivalry such as chapter 34 of Al-Resala Al-Gheshrieh by Abu-al-Ghasem Ghosheiri (d 465 AH) (Ghosheiri, 1988).

which contains different aspects of chivalry. In the next centuries, these chapters were replaced with chivalry treatise such as Alfotowah by Solomi, Merat-al-Morowah (mirror of chivalry) by Ali-ebne-Hassan-ebne-Jawdavieh (contemporary with khaje Nezam-al-Molk Toosi), Fotowat-Nameh by khaje Abdulah Ansari, Resalat-al-Fotowah by Akhi Ahmad Almoheb-ebne-Sheikh Mohamad Mikayeel Ardabili and Resala-al-Fotowah by Shahab-al-Din Sohrevardi, author of Avaref-al-Maaref, (d 632 AH). This is important for two 
reasons, first it shows the relation between Chivalry and Sufism and second it explains prevalent terms and phrases of chivalry in that era. They called student (Taleb) as Tarabieh and Akhy and Sheikh of Fotowat-khaneh as Saheb (Sarraf, 2000).

In addition to the close relation between chivalry and Sufism, this Sufi institution had relations with guilds and primary Malamatieh groups which were not infected with inward and outward insouciance to mystic morality of the society and Sharia (Afifi ,1997).

At the late $5^{\text {th }}$ Hegira century, Sufis lived in Arab Iraq linked with guild institutions of Iranian cities and chivalry found an independent identity alongside public Sufism. Chivalrous had their own traditions proportional to guild groups linked to them. These traditions such as the initiation of chivalry to clothing (like chivalry trousers instead of Sufi's cloak) and using special expressions(Golpinarli, 2000), provided a circumstance based on which chivalrous were known by other names in the society like Ayaran, Daravish and Shattaran (Riaz, 2003). As a result of historical evolution, chivalry followers gradually kept out of Sufism tradition. In the era of Abbasid caliph, Al-Naser-le-din-Allah (ruled from 575-622 AH) insurgent Ayyaran and chivalrous men of Iraq rioted, so the caliph put on chivalry trousers to lead chivalry followers in order to calm down the insurgence. (Note 3) Accordingly, chivalry played role in political movements and social rebellions. In the following section, the trend of chivalry in Azerbaijan will be reviewed based on the evidences mentioned in references.

\section{Chivalry in Azerbaijan before Mogul Dominance (Akhys)}

The first Azerbaijan Sufi held title of Akhy was Akhy Faraj Zanjani and chivalrous of Azerbaijan were his disciples. He held this title exclusively and his sheikh title sign was obvious in his chivalry not by the tradition of Sufis in Khangah, where they call each other akhy (Ebadi Marvzi, 1983). There's little information on Akhy Faraj Zanjani's life. One can guess that he got the title of Akhy from Turkmen Sufis and darvishes, because baleh in Razi dialect (Iranian dialect spoken in Azerbaijan $10^{\text {th }}$ Hegira century) is equal to Akhy (Karbalayee, 1970). As recent researches show, Akhy is derived from Aky which means chivalrous in Turkish (Bayram, 1991).

Akhys were urban and they had jobs and they lived in Langar and Astana (Ebne-Batooteh, 1958). The origin of Akhy refers to Islamic brotherhood which was promoted by Prophet Muhammad among Muhajerin (Immigrants) from Mecca and Ansar (Helpers) from Medina and is quoted in Quran (Hojorat, verse 10). Many of Islamic world's sheikhs are called with the title of Akhy who followed chivalry traditions (Riaz, 2003).

Akhys and their gatherings could be found in all Islamic territories, but they were more impressive in Asia Minor. Until $8^{\text {th }}$ century, they had diver in their places (temples) and played music. They wore white cassock known as Ghalansoo. They put a shawl on their shoulder and held a knife in their belt which was carried everywhere. They put a wool hat on their head made of fez (Nafisi, 1964).

Urban chivalrous were warriors and disrupted security of cities. Governments tried to control them and made them obey and made use of them for conflicts and law enforcement in cities (Afshari, 2009). 
It was after Akhy Faraj Zanjani (d $454 \mathrm{AH})$ that Sufism in Azerbaijan mixed with chivalry and chivalrous Sufis (fats) pleaded oppressed people in tensioned Azerbaijan. Prior to Mogul dominance on Azerbaijan, chivalry manner was seen in some Sufis such as baba Faraj Tabrizi, Master Nam-aldin Kobra (d 618 AH) who knew science of psychology (Elm-e-Nazar) and had rapture whilst being active in social affairs. Faghi Zahed Tabrizi (d 592 AH) who was a Sufi follower of Joneyd Baghdadi and one of the masters of Ovhad-aldin Kermani is assumed as chivalrous. Baba Hassan Vali Sorkhabi (d $610 \mathrm{AH})$ who assumed himself as Adhamieh and followed Akhy Faraj Zanjani was also a chivalrous. He was baba of 70-babas and wore black cloak. Baba Mazid (d 620 AH) a chivalrous who followed Khosravni wisdom (Hekmat) of sheikh Shahab-aldin Shorevardi used baleh in his speech equal to Akhy in common language of Tabriz in that period. (Note 4) He took the title of Akhy form his master Akhy Faraj Zanjani. Baleh in Azari language is equal to Akhy, both phrases are evidence of chivalry and brotherhood manner. Calling Sufis in Khanghah as Akhy was a tradition for people and they called each other ey akhy! regardless to the ranks and positions. Many documents such as Asrar-al-Towhid and Attar books and Masnavi, etc. quoted the use of this phrase and its commonality among chivalrous (Attar, 2004).

Baleh Khalil Sufi was another chivalrous of that period. Confidence of Amir Vas-hoodan the ruler of Tabriz to baleh Khalil in supervising renewing ruined buildings of $433 \mathrm{AH}$ of Tabriz earthquake (Karbalayee, n.d.). (Note 5) confirms that he had both Sufism and chivalry which is the evidence of his fame and respect among people. According to the date of earthquake and presence of baleh Khalil in charity works and helping suffered people, one can assume baleh Khalil Sufiani (Marandi) as the head of connection between Khanghah and chivalry Sufism in Azerbaijan.

In the late $5^{\text {th }}$ century, Azerbaijan witnessed a Sufi known as Khajeh. His name is Khajeh Muhammad Khoshnam Nakhjavani who is buried in Khajeh Khoshnam village near Tabriz (ibid, 1/2). Reviewing his biography in Rowzat-al-Jennan, the only reference in this field, shows that he was disciple of Akhy Faraj Zanjani and was a well-known chivalrous who spread Mohaghaghe (Note 6) manner in Azerbaijan for the first time. He is the first Azerbaijani Sufi with a written biography.

But there's little information about Akhy Faraj Zanjani whose disciples, baleh Khalil and Khajeh Khoshnam propagated chivalry-based Sufism in Azerbaijan. Hajviri only mentioned his name (Hojviri, 1969). Jami mentioned him as a disciple of Abu-al-Abbas Nahavandi(Jami, 1991). in Nafahat-al-Ons and reaffirmed his munificence (Attar, 1957). Hafez Hossein Karbalayee quoted another munificence for him the same as one reffered to Sery Saghati (d $253 \mathrm{AH}$ ), the moderate and pious Sufi from Baghdad (Karbalayee, 1349). Jami mentioned that Akhy Faraj Zanjani died at 457 AH but Hafez Hossein Karbalayee wrote that his death happened at 454 AH. It was just Seyed Muhammad Noorbakhsh that introduced Akhy Faraj Zanjani as Selselat-al-Owlya in such a way that his position can be understood: "He was a great sheikh and a top pious mystic with titles and positions and munificence and revelation and died at 454 AH"(Noorbakhsh Ghahestani, 1970).He was preceptor of some well-known Sufis of Azerbaijan. His disciples established chivalry-based Sufism in Azerbaijan (Karbalayee, 1970). 
Azerbaijan experienced hard days after the death of Nosrat-aldin Abdullah Pahlevan in 607 AH, when Muzafar-aldin Uzbek became the ruler of Azerbaijan. Successive invasions of Georgians to northern cities of Ardabil, Meshkin, etc. and occupation of Tabriz by Jalal-aldin Kharazmshah in $622 \mathrm{AH}$ and internal struggles of ministers and incompetence of the governors and misbehavior of them with people suffered Azerbaijan citizens. At this time two major Sufis of Azerbaijan guided their disciples and followers. Baba Hassan Vali Sorkhabi (d $610 \mathrm{AH}$ ) (Tarbyat, 1387) who was the son of them with a thriving Khanghah. He was baba of 70-babas and was a master for many Sufis (Karbalayee, 1970). Baba Hasan, like most of Azerbaijan sheikhs, did not teach and write note like classic trainers, but Sheikh Muhammad Shabestari mentioned some of his ideas and empathy in Saadat Nameh(Shabestari, 1986). For example, one can interpret his comments in "optional death" (Note 7) as a disclaimer of life and daily events. Baba Hasan's devotion goes back to Akhy Farj Zanjani (Hashri, 1992). However, some references relate him to Adhamieh who were in connection with Ibrahim Adham (d 166 AH), a great Sufi from Khorasan. Baba Hassan and his successors wore black cloak (Karbalayee, 1970). The creed of black cloak spread its domain of activity to Ardebil and competed with the followers of Sheikh Safi-aldin Ardebili (d $735 \mathrm{AH})$ in the $8^{\text {th }}$ century. They were not favorable for successors of Sheikh Safi, which resulted in conflicts between Khangahs reflected in Rowzat-al-Jennan as: "Good for who forget color and glamor of this earthly life and get mortal by the ignorance of the colors"(ibid). It seems that regardless to the difference of colors in mystic view and their priority which is mentioned in Sufism references (Korban, 2013). Black cloak were a group of chivalry known as 70-baba who followed Akhy Faraj Zanjani manner to help stricken people of Azerbaijan in such hard situation. An evidence for this claim can be found in Safwat-al-Safa describing one of the leaders of black cloak: Evaz, one of the leaders of black cloak, headed Sheikh Safi Khanghah to discuss with him in order to prevent the tendency of black cloak followers to Sheikh Safi manner and prevent connections of them as a free and popular group with conservative and power-demand Khanghah institution. Turk agents of the government beated Evaz and arrested him. These Turks who had the political power supported sheikh Safi-aldin Khanghah (Mezavi, 1984). There's no more information on chivalry-based Sufism prior to Mogul dominance on Azerbaijan.

\section{Chivalry in Azerbaijan after Mogul Dominance}

After dominance of Mogul on Azerbaijan, social turmoil increased and Sufism inspired by chivalry, Akhys and Babas spread more than before. Fast-changing governments of Azerbaijan and despotism and cruelty of Mogul commanders and competition of local governors did not provide government operatives with enough time to tackle the problems of Azerbaijan, (Note 8) So Sufism and chivalry found good chance to spread in the second half of $7^{\text {th }}$ Hegira century and promoted Sohraveye and Kabraveye among itself. This characteristic of Sufism cannot be found anywhere else in Iranian territory.

In this period, Azerbaijan Sufism did not disconnect its relation with Khorasan and as mentioned earlier, the need for facing with social crisis, made chivalry as a specific characteristic and Sufism was assumed as a heritage of chivalry. Such evidences can be found in people like Akhy Avren Khoyee (d $659 \mathrm{AH}$ ) who reinforced this Sufi institution even in 
Anatoly and Sheikh Shahab-aldin Ahari (d $665 \mathrm{AH}$ ) who played an important role in Sufism in Azerbaijan. He showed another face of Sufism inspired by chivalry in Azerbaijan and by achieving Qitb position and training disciples (chivalrous/akhys) introduced himself as the connection point between Shari-based Sufism related to Safi-aldin Ardabili and chivalry-inclined Sufism which was a domestic appearance of Azerbaijan Sufism after Akhy Owran. Considering the name of Akhy Avren, it's obvious that Akhys were active in Azerbaijan during Ilkhani period.

The life of Abu-al-Haghayegh Nasir-aldin Mahmud-ebne-Ahmad Khoyee (556 to 659 AH) known as Akhy Avren, master of tanners guild and the founder of Akhyan manner in Anatoly has been described as a myth in many biographies. He was Avhad-aldin Kermani's son-in-law. Avren is the name of a mountain and a village in the west of Khoy and it means dragon in Turkish language and remind braveness of Akhy Avren in tanners' guild and the institution of Anatoly Akhys (Dyanat, ). It's obvious that he got familiar with Sufism and chivalry during his youth ages in Azerbaijan and went Khorasan and Transoxiana and learned Sufism manner from disciples of Ahmad Yasvi (Note 9) (d 562 AH). After pilgrimage of Mecca, he got familiar with Avhad-aldin Kermani and started learning from him. Majd-aldin Eshagh, father of Sadr-aldin Ghonavi (d $673 \mathrm{AH}$ ) urged him to travel Anatoly and stay there safe away from political turmoil of Azerbaijan. He lived there in the cities of Denizly, Ghoneyeh and Gheysarieh and opened a tanning shop in Gheysarieh. He was allowed to guide Sufis by the permission of Sadr-aldin Gharnavi. He established Akhys' institution in Gheysarieh and gained such a credit that Ez-aldin Keykavos the second, Seljuk king of Rome, announced his support for this institution and made use of Akhys force and power of tanners and shoemaker's guild who had relations with Akhys in political orientation and opposition with Mogul dominance. After Mogul invasion of Anatoly, two groups were active there. One group believed that their power and governance will be secure if they compromise and obey Moguls with some Sufis among them and the other group believed that fighting with Moguls and securing independency in policy and economy is a better way. The first group was attractive for Moguls and their united local governors. But Baktashi manners under the leadership of Haji Baktash (d 669 AH) mostly consisted of Turkmens and disciples of sheikh Avhad-aldin Kermani and akhys who followed Akhy Avran Khoyee and owners of guilds were the second group which made special political and social movements in Anatoly. It's possible that Shams-e-Tabrizi had been killed by Akhy Avran's followers (Orojnia, 2000; Bayram, 2000) because his ideas and Rumi's were equal to the first group.

There are some essays in Farsi written by Akhy Avren which are not so long and were proper for urban craftsmen. Mikayeel Bayram presented a complete list of them in his book entitled "Akhy Avran and the onset of Akhys institution in Anatoly" (Bayram, 2000). Some of them are treatise of onset and destiny, such as Latayef Ghyasah, Katayef-al-Hekmah prepared for Seljuk Keykavoos, praise of thought and blame of universe, Manhej-al-Seifi, Matale-al-Aman, Morshed-al-Kefayeh in which mostly the anti-oppression idea of Sufism had been promoted.

Thereafter, a group appeared known as Pahlevans (champions) who were professional in martial arts and physical power. They were called by other names like mofrad, yatim, baba, 
ehdas, bahador, javan and kohne-savar. Pahlevans had relations with king's courts and were somehow involved with policy and important social issues of Iran especially in Safavid period. Some references and old texts mentioned thefts, loaf and murders done by pahlevans frequently, but this is not the whole story, group of pahlevans were religious and even some of them were scholar and were engaged with science and debate (Afshari, 2009) like sheikh Shahab-aldin Mahmud Ahari (Note 10) (d 665 AH). He was the most famous mystic of Azerbaijan after Khajeh Muhammad Kajjani. He experienced period of Hulaku khan and Abagha khan in Azerbaijan and followed Sufism manner during the peak of social-political turmoil in the late $6^{\text {th }}$ and the early $7^{\text {th }}$ Hegira century during the silence of his hanghah in Ahar. Ahar was assumed as an important city not only for the existence of mintage (Fayeghi, 1996) shop but also for the connection it made between Tabriz and Ardabil in Molok-e-Ahar (Note 11) period. This city has an important role in the growth of Azerbaijan Sufism, because Shahab-aldin Mahmud Ahari the connecting point of Sohravardieh manner related to Abu-Najib Sohrevardi from Sohrevard Zanjan (d 517 AH) and Safavid manner related to Sheikh Safi-aldin Ardabili (d 735 AH) lived in this city.

He traveled to Tabriz like many other youth who were eager to learn science and Sufism and got title of pahlevan there. There in Tabriz, Sheikh Rokn-aldin (Sejasi) (Note 12) met him and educated him. (Note 13) Sheikh Mahmud Ahari had a temple (Note 14) beside a campanile and Sheikh Safi-aldin Ardabiliy stayed there when arrived at Tabriz. Sheikh Mahmud Ahari trained many disciples including Sheikh Jamal-aldin Tabrizi who transferred his guidelines to Sheikh Safi-aldin Ardabiliy. Among other disciples, one can mention Sheikh Moyeen-aldin Ashab, master Sheikh of baleh Hassan Benisi and baba Faraj Vayghani who had three complementary disciples. Training disciples, he became head of baba dynasty of Tabriz and Azerbaijan consisting of chivalry and urban Akhys who led social organizations (guilds) and had important political role in chaotic urban society of late Atabakan period and during authoritarianism of king Jalal-aldin Kharazmshah and massacre of Moguls (Golpinarly, 2000; Alsheibi, 1985).

According to the above mentioned discussion, the importance of Sheikh Mahmud Ahari can be summarized in some items: First he was the head of a Sufi dynasty known as baba and as mentioned it's assumed as a branch of chivalry and Akhys system. He inherited devotion, repentance, empathy and gentry of Sheikh Safi via Sheikh Zahed Gilani and Seyyed Jalam-aldin Tabrizi. So, he was attended by Safavid and their kings who respected his sepulcher in Ahar and attempted to attract disciples for his manner in order to make use of their physical power. According to Safavid period, references such as Tazkare Nasrabadi and Tazkarat-al-Molook baba names were highlighted in Safavid period. Also according to text of Rowzat-al-Athar, Safavids respected Rokn-aldin Sejasi, one of chivalry masters and followers of Sohravardieh and his disciple Sheikh Shahab-aldin Mahmud Ahari and tried to transfer the extract of social Sufism (chivalry) of Tabriz to Ardabil via Ahar. It can be confirmed that Shahab-aldin Ahari wrote three books of verse essay of love, Farayez and Mokhtasare Farayez (Hojviri, 1957). 


\section{Conclusion}

The presence of chivalrous in each society was a response to economic and social abnormalities and sometimes was a sign of activities of them serving political groups and securing their interests. According to historical sources, chivalry in Azerbaijan began with Akhy Faraj Zanjani in late $5^{\text {th }}$ century and his chivalrous followed him were beside people in political and social crisis and were considered as haven for them. Most group of chivalrous who were active in Azerbaijan consisted of Akhys and Pahlevans were followers of Sharia and mostly had occupation and took part in guilds. Chivalrous sometimes were called baba and 70-baba was an important title among them and they even used special colors in their institutions. After Mogul invasion to Azerbaijan, most of Sheikhs migrated and chivalrous were not exception. Most of them traveled to Anatoly and were active and effective there that fought with the cruelty of Mogul. There were Pahlevans among chivalrous whose main power was prevailing selfishness. Azerbaijan chivalrous had some essays concentrated on fighting against cruelty. They had an important role in handling issues dealt with Azerbaijan ordinary people.

\section{References}

Afifi, A. (1997). Malamatia and Sufism and Chivalry. Translated by Nasrollah Forohar, Tehran, Elham publication.

Afshari, M. (2002). Fourteen treatise on chivalry and guilds. Tehran, Cheshme publication.

Afshari, M. (2009). Chivalry and Guilds. Tehran, Ancient Iranian Texts.

Al-sheybi, M. (1964). Al-seleh bayna tasavof va tashayoh. Baghdad.

Attar, F. (2004). Mantegh-al-Teyr. Edited by Muhammad Reza Shafiee Kadkani, Tehran, Sokhan.

Banakati, F. (1969). History of banacati. Edited by Jaafar Shoar, Tehran, publication of National works Association.

Bayram, M. (1991). AHỈ evren, veahi teskil. tinin Kurlusu, Konya.

Bayram, M. (2000). Ovhad-ladin Kermani and Ovhadieh Movement. Translated by Mansooreh Hosseini and Davood Vafayee, Tehran, Nashr-e-Markaz.

Ebadi Marvzi, M. (1983). Managheb-al-Sowfieh, edited by Najib Mayel Heravi, Tehran, Mowla publication.

Ebne-Batooteh, M. (1958). safar nameh. Translated by Muhammad Ali Movahed, Tehran, Tarh-e-No publication.

Ebne-bibi, H. (1957). Al-Avamer-al-Aalayee fi al-omor al-Aalayee. Edited by Nejati Oghal and Adnan Sadegh Arzi, Anghre.

Eghbal, A. (1986). History of Mongol. Tehran: Amir Kabir Publication.

Eghbal, A. (1986). Mogul History. Amirkabir publication. 
Fayeghi, I. (1996). Azerbaijan in the path of Iran history. Tabriz, Yaran publication.

Ghosheiri, A. (1988).Resala-al-Ghoshrieh. Translated by Abu Ali Hassan-ebne-Ahmad Osmani, corrected by Badi-al-Zama Forozanfar, Tehran, Elmi va Farhangi publications, third edition.

Golpinarly, A. (2000). Chivalry in Islamic countries. Translated by Tofigh Sobhani, Tehran, Rozaneh publication.

Hamednai, R. (1994). Jame-al-Tavarikh. Edited by Muhammad Rooshan-Mostafa Mosavi, Tehran, Alborz publication.

Hashari, M. (1992). Rowzat Athar. Edited by Aziz Doolat Abadi, Sotodeh publication.

Hojviri, A. (1957). Kashf-al-Mahjoob. Edited by Valentine Zhokovski, Tehran, Amirkabir.

Islam world Encyclopedia. (1379). Supervised by Mostafa Mirsalimm, Tehran.

Islamic Great Encyclopedia. (1995-2004). Supervision by kazem Mousavi Bojnordi, Tehran: Encyclopedia Center.

Jami, N. (1370). Nafahat-al-Ons men Hazarat-al-Qods. Edited by Mahmud abedi, Tehran, Etelaat publication.

Joveiny, A. (1950). Jahangosh History. Edite by Muhammad Qazvivni, Bril India.

Karbalayee, H. H. (1970). Rowzat-al-Jennan va Jenat-al-Jennan. Edited by Jaafar Soltan Algahrayee, 2 volumes, Terhan, Bongahe nashr va tarjome.

Karbon, H. (2013). Illuminated man in Iranian Sufism. Translated by Faramraz Javaheri nia, Tehran, Amoozgar-e-Kherad publication.

Mezavi, M. (1984). Appearance of Safavid government. Translated by Yaaghub Azhand, Tehran, Gostareh.

Movahed, M. (1996). Shams-e-Tabrizi. Tehran, Nashre-No publication.

Nafisi, S. (1964). Source of Sufism in Ran. Tehran, Foroghi publication.

Noorbakhsh Ghahestani, M. (1970). Selsele-al-Owlya. Edited by Muhammad Taghi Danesh Pazhooh, Indexed in Henry Karbon memorandum, Tehran.

Oryan, S. (1992). Pahlavi Texts. Tehran, National Library.

Pigolo Sekaya, N. (1993). Iran cities in Parthian and Sasanian periods. Translated by Enahat-allah Reza, Elmi-va-Farhangi Publications.

Riaz, M. (2003). Fotowat-Nameh (History, tradition and faith). Tehran, Asatir publication.

Saraf, M. (1973). Treatise of chivalrous. Tehran, French Institute of Scientific Research in Iran. 
Shabestari, M. (1986). Series collection. Edited by Dr. Samad Movahed, Tehran, Kharazmi publication.

Tarbyat, M. (2008). Azerbaijan scholars. Edited by Gholamreza Tabatabayee Majd, Tehran, Ministry of Culture and Islamic guidance.

Zambaver, E. (1997). Pedigree of caliphs and rulers. Translated by Muhammad Javad Mashkoor, Tehran, Khayam publication.

\section{Notes}

Note 1. According to historical evidences both in western and Iranian documents regardless to little changes during history, Azerbaijan geographical territory limited from north to Aras river and Ararat Mountains, from west to Zagros Mountains, from south to Orumyieh lake and from east to Ghezel Owzan river (Sepid river- in Mogul Hoolan Mooran) and Talesh Moutaians. Islamic geographers considered Nakhjavan in the other side of Aras River as a part of Azerbaijan (zaryabe Khooyee, 2000, 206/1). Formation of Iran northwestern province in Sasanian period which was controlled by one of four governors (Pigolo Sekaya, 1993, 242) named Azarbazgan Esbahbaz shows the importance of Azerbaijan in Sasanian period and early Islamic era. Although just two cities of Ganzak and Orumiyeh were mentioned in Pahlavi and Zoroastrian texts (Oryan, 1992, 69).

Note 2. This is explained in details in the book of Al-Fotowah written by Solomi: Solomi, Abdu-al-Rahman (1397 AH).

Note 3. Urban Ayyars were warriors and disrupted security of cities. Governments tried to control them and made them obeyed and made use of them for conflicts and law enforcement in cities. (Afshari, 2002, 20). Ez-al-din Keykavo followed Abbasid caliph in order to make chivalrous and sheikhs obeyed in Asia Minor (Ebne-bibi, 1957, 1/217-223).

Note 4. Baleh, in Razi language, great, chivalrous and selfless (Karbalayee, 1970, 2/83).

Note 5. Amir Vas-hoodan gathered scholars and sheikhs such as Abu-Nasr al-NAjafi, Khalil Sofiani, sheikh Abu-Ali Ayoban, sheikh Sayeed Samool. For more information on akhys role in building society and rural areas, etc (Golpinarly, 118-120).

Note 6. Purpose of Mohaghaghiyeh Sufism is the Sunni groups and Hajviry categorized them against Halolian and Halajian and Abahatyan, etc. who are rejected by Sufism (Hojviry, 164).

Note 7. Sufis term of optional death means, opposition with selfishness and subdue and bridle it which is the most fundamental task of a disciple (Movahed, 1996, 53).

Note 8. When Mogul ruled on Azerbaijan, all Iran territory was chaotic and Azerbaijan after invasion of Sobtay Vajebah in $618 \mathrm{AH}$ was handed to GoorGooz like other parts of the country (Benakati, 1969, 390). Although he was one of the actuaries of Oyghoori Saleh and attempted to develop his territory (Joveiny, 1950, 2/238), but presence of various Mogul governor in Iran with vast amount of authority made situation hard for him and each princess 
of Genghis had his own army and agents and compete to get more power. As a result of this competition GooGooz was murdered after death of Oktay when Toorakina Khatoon received the crown (639 AH) and Amir Arghvan assigned as ruler of Iran and Azerbaijan (ibid, 2/243). According to Joveyni when he came to Tabriz, Azerbaijan people and local agents refuge him against Mogul commanders like Joraamoon and Bayjoo (ibid, 2/244). He was a cute man but had the difficulties of GoorGooz, so he handed Azerbaijan to Baha-aldin Joveini and returned back to Toos (Eghbal, 1986, 169). Early death of Giok handed Mogul kingdom to ManguQaAn. He assigned Holako khan as ruler of western parts of Iran and Armenia and Levant (Rashid-aldin Fazl-allah ,1994, 2/685). After death of Holaku khan in 663 AH AbaQa kahn had the chance to rule Azerbaijan.

Note 9. Ahmad Yasvi (d 562 AH), Great Sufi of Transoxiana lived most of his life with migrating Turk tribe near Seyhoon river (Pursobhani, 7/117).

Note 10. In Selesleh-al-Owlya name of this person registered as Shahb-aldin Mahmud al-Tabrizi al-Aatighi al-Ahari (Noorbakhsh, 45).

Note 11. Georgian converted to Islam assigned to rule in Ahar by Atabaks. Pishtakin-ebne-Muhammad assigned by Grand-pahlevan Ildgaz and Nosrat-aldin Mahmud-ebne-Pishtakin (around 587 to 623) known as Molok-e-Ahar. (zambavre, 1977, 296).

Note 12. One of the connections to Sohravardieh dynasty via Qotb-aldin Abhari (d $577 \mathrm{AH})$.

Note 13. He took the title of Qotb and was the greatest master of his period. Seyed Jamal-aldin Tabrizi was one of his disciples and Sheikh Zahed Gilani was a disciple for Seyed Jamal-aldin Tabrizi and finaly Sheikh Safi-aldin Ishagh Ardabili was disciple of Sheikh Zahed Gilani (Hashri, 146 to 147).

Note 14. Use of temple phrase by Karbalayee for khanghah or Zaveye of Sheikh Mahmud Ahari can lead us to conclude that this sheikh was mostly bust with worship and did not Sema or other actions common among Sufis (Karbalayee, 2/68).

\section{Copyright Disclaimer}

Copyright for this article is retained by the author(s), with first publication rights granted to the journal.

This is an open-access article distributed under the terms and conditions of the Creative Commons Attribution license (http://creativecommons.org/licenses/by/3.0/). 